\title{
Neurotensin is a proinflammatory neuropeptide in colonic inflammation
}

\author{
Ignazio Castagliuolo, ${ }^{1}$ Chi-Chung Wang, ${ }^{1}$ Leyla Valenick, ${ }^{1}$ Asiya Pasha, ${ }^{1}$ \\ Sigfus Nikulasson, ${ }^{2}$ Robert E. Carraway, ${ }^{3}$ and Charalabos Pothoulakis ${ }^{1}$
}

${ }^{1}$ Division of Gastroenterology, Beth Israel Deaconess Medical Center, Harvard Medical School, Boston, Massachusetts 02215, USA
${ }^{2}$ Department of Pathology, Boston Medical Center, Boston University School of Medicine, Boston, Massachusetts 02118, USA
${ }^{3}$ Department of Physiology, University of Massachusetts Medical Center, Worcester, Massachusetts 01655, USA

Address correspondence to: Ignazio Castagliuolo, Division of Gastroenterology, Dana 501, Beth Israel Deaconess Medical Center, 330 Brookline Avenue, Boston, Massachusetts 02215, USA. Phone: (617) 667-1260; Fax: (617) 975-5071;

E-mail: icastagl@bidmc.harvard.edu

Received for publication June 8, 1998, and accepted in revised form February 4, 1999.

\begin{abstract}
The neuropeptide neurotensin mediates several intestinal functions, including chloride secretion, motility, and cellular growth. However, whether this peptide participates in intestinal inflammation is not known. Toxin A, an enterotoxin from Clostridium difficile, mediates pseudomembranous colitis in humans. In animal models, toxin A causes an acute inflammatory response characterized by activation of sensory neurons and intestinal nerves and immune cells of the lamina propria. Here we show that neurotensin and its receptor are elevated in the rat colonic mucosa following toxin A administration. Pretreatment of rats with the neurotensin receptor antagonist SR-48,692 inhibits toxin A-induced changes in colonic secretion, mucosal permeability, and histologic damage. Exposure of colonic explants to toxin A or neurotensin causes mast cell degranulation, which is inhibited by SR-48,692. Because substance $\mathrm{P}$ was previously shown to mediate mast cell activation, we examined whether substance $\mathrm{P}$ is involved in neurotensin-induced mast cell degranulation. Our results show that neurotensininduced mast cell degranulation in colonic explants is inhibited by the substance $P$ (neurokinin-1) receptor antagonist CP-96,345, indicating that colonic mast activation in response to neurotensin involves release of substance $\mathrm{P}$. We conclude that neurotensin plays a key role in the pathogenesis of $C$. difficile-induced colonic inflammation and mast cell activation.
\end{abstract}

J. Clin. Invest. 103:843-849 (1999).

\section{Introduction}

A growing body of evidence suggests that interaction of epithelial and immune cells via neuropeptides, hormones, and cytokines participate in the pathophysiology of diarrhea and intestinal inflammation (reviewed in ref. 1). Neurotensin (NT), a bioactive peptide (2) with a primary distribution in the brain and the gastrointestinal tract, has been localized by immunohistochemistry to endocrine cells ( $\mathrm{N}$ cells) and neurons in the intestinal mucosa, submucosa, and muscularis of animals and humans (3). A wide range of biological activities has been described for NT with actions on the cardiovascular, gastrointestinal, reproductive, and central nervous systems (3). The known intestinal effects of this peptide include trophic effects on small and large bowel, pancreas, and stomach; inhibition of small bowel and gastric motility; and stimulation of colonic motor activity (3). Studies in animals $(3,4,5)$ and humans $(3,6)$ also demonstrate that NT may modulate fluid secretion in the intestinal tract and that its secretory effects in the ileum may be mediated through a nervous reflex in the enteric nervous system (5).

Several lines of evidence indicate that NT may also participate in inflammatory reactions. Intravenous administration of NT to rats causes mast cell degranulation (7) and increases vascular permeability and levels of histamine and leukotriene C4 in the plasma (8); these effects can be inhibited by a specific NT receptor antagonist (9).
NT also interacts in vitro with immune and inflammatory cells, including leukocytes (10), peritoneal mast cells (7), and macrophages $(11,12)$. Although these studies point to a role for NT in inflammatory reactions, the possibility that this peptide participates in the pathogenesis of colonic inflammation has not been examined.

NT exerts its effects by interacting with specific receptors (NTR) on cell surfaces. Two specific receptors for NT (NTR1 and NTR2), which belong to the seven transmembrane $G$ protein-linked superfamily, have been identified and cloned $(13,14)$. NTR1-mRNA and NT binding sites have been identified in the brain (15), small and large intestine of animals and humans $(13,15)$, human colonic epithelial cell lines $(16,17)$, human blood mononuclear cells (11), and endothelial cells (18). Recently, we demonstrated the presence of NTR1 mRNA in the rat colonic mucosa, including colonic epithelial cells (19). We also showed that administration of the specific NT receptor nonpeptide antagonist SR-48,692 to rats attenuated colonic mucin secretion and mast cell activation following immobilization stress, indicating a critical role for NT in stress-related colonic responses (19).

Clostridium difficile is the primary pathogenic factor of antibiotic-associated diarrhea in humans and animals (reviewed in ref. 20). C. difficile induces colitis, releasing two exotoxins: toxin A and toxin B (20). Both toxins cause cell rounding through inactivation of the family of Rho pro- 
teins (21) and damage human colonic mucosa in vitro (22). In addition, injection of toxin $\mathrm{A}$ into intestinal loops of rodents triggers fluid secretion, increases mucosal permeability and neutrophil (PMN) infiltration, and causes epithelial cell necrosis $(23)$. We $(23,24)$ and others $(25)$ have provided evidence that primary sensory neurons containing substance $\mathrm{P}(\mathrm{SP})$ are involved in the early stages of toxin A enteritis. Furthermore, activation of mast cells (26) and macrophages (24) and recruitment of circulating PMNs (27) are important steps in toxin A-induced intestinal inflammation.

In this study, we used the rat colonic loop model in which toxin A induces fluid secretion and inflammation to investigate the possibility that NT participates in colonic inflammation. We also correlated the levels of NT and NTR1 expression with the time-course appearance of colonic secretion, epithelial cell damage, and inflammation in response to $C$. difficile toxin A. Because we previously reported an important role of SP in C. difficile toxin A-mediated intestinal mast cell activation, we also explored the possibility of cross talk between NT and $\mathrm{SP}$ in this intestinal response.

\section{Methods}

Measurement of colonic NT content. The proximal colon of fasting $(16 \mathrm{~h})$, anesthetized (single intraperitoneal injection of sodium pentobarbital, $35 \mathrm{mg} / \mathrm{kg}$; Abbott Laboratories, Chicago, Illinois, USA) male Wistar rats (200-250 g) was used in all the experiments. One $5-\mathrm{cm}$ loop was constructed and injected either with toxin A $(5 \mu \mathrm{g})$, purified as described previously (23, $24,26)$ in $0.4 \mathrm{ml}$ of $50 \mathrm{mM}$ Tris buffer ( $\mathrm{pH} 7.4$ ), or with buffer alone (control). At various time intervals, the animals were sacrificed by an intraperitoneal pentobarbital overdose (120 $\mathrm{mg} / \mathrm{kg}$ ), and loops were removed, opened, and washed in icecold HBSS (Sigma Chemical Co., St. Louis, Missouri, USA). The mucosa was then scraped from the underlying muscularis, homogenized in $2 \mathrm{ml}$ of ice-cold $0.1 \mathrm{~N} \mathrm{HCl}$ for $20 \mathrm{~s}$, and centrifuged $\left(15,000 \mathrm{~g}\right.$ for $15 \mathrm{~min}$ at $\left.4^{\circ} \mathrm{C}\right)$; the supernatants were prepurified on C18 cartridge columns (Waters Corp., Milford, Massachusetts, USA) that were washed with $10 \mathrm{ml}$ methanol and equilibrated with $0.1 \%$ trifluoroacetic acid (TFA). Samples were diluted $1: 1$ with $0.2 \%$ TFA and loaded onto the column, which was then washed with $10 \mathrm{ml}$ of $0.1 \%$ TFA. Adsorbed peptides were eluted with $1.5 \mathrm{ml}$ of $75 \%$ acetonitrile. Samples were freeze-dried in a Speed-Vac concentrator (Savant Instruments Inc., Hicksville, New York, USA) and reconstituted in $0.5 \mathrm{ml}$ of

\section{Table 1}

Effect of toxin A on rat colonic fluid secretion, mucosal permeability, and histologic severity of colitis

\begin{tabular}{llcccc}
\hline & $\begin{array}{c}\text { Intestinal } \\
\text { secretion } \\
(\mathrm{mg} / \mathrm{cm})\end{array}$ & $\begin{array}{c}{\left[{ }^{3} \mathrm{H}\right] \text { mannitol }} \\
\text { permeability } \\
(\mathrm{dpm} / \mathrm{cm})\end{array}$ & $\begin{array}{c}\text { Epithelial } \\
\text { damage }\end{array}$ & $\begin{array}{c}\text { Histologic severity } \\
\text { Congestion and } \\
\text { edema }\end{array}$ & $\begin{array}{c}\text { Neutrophil } \\
\text { infiltration }\end{array}$ \\
Control $(4 \mathrm{~h})$ & $150 \pm 8$ & $1,222 \pm 411$ & $0.2 \pm 0.1$ & $0.3 \pm 0.2$ & $0.2 \pm 0.2$ \\
0.5 h toxin A & $160 \pm 9$ & $922 \pm 112$ & $0.2 \pm 0.2$ & $0.6 \pm 0.2$ & $0.2 \pm 0.2$ \\
1 h toxin A & $211 \pm 7$ & $1,553 \pm 170$ & $0.4 \pm 0.2$ & $0.8 \pm 0.2$ & $0.2 \pm 0.2$ \\
2 h toxin A & $325 \pm 11^{\mathrm{A}}$ & $3,542 \pm 533^{\mathrm{A}}$ & $0.4 \pm 0.2$ & $2.0 \pm 0.3^{\mathrm{B}}$ & $1.0 \pm 0.1^{\mathrm{A}}$ \\
$4 \mathrm{~h}$ toxin A & $436 \pm 17^{\mathrm{B}}$ & $9,681 \pm 904^{\mathrm{B}}$ & $2.0 \pm 0.3^{\mathrm{B}}$ & $2.2 \pm 0.3^{\mathrm{B}}$ & $2.4 \pm 0.2^{\mathrm{B}}$
\end{tabular}

A proximal colonic loop was constructed in fasting, anesthetized male Wistar rats and injected with either $5 \mu \mathrm{g}$ of toxin A or buffer (control). At the indicated time points, animals were sacrificed, colonic loops were removed, and fluid secretion was measured as loop weight $(\mathrm{mg})$-to-length $(\mathrm{cm})$ ratio. Mucosal permeability to $\left[{ }^{3} \mathrm{H}\right] \mathrm{man}$ nitol was quantitated by scintillation counting of aliquots of loop samples, and results were expressed as disintegrations per minute $(\mathrm{dpm})$ per centimeter of loop. Samples from colonic loops were processed as described for histologic examination. The histological severity was graded by a score of $0-3$, taking into account epithelial cell damage, congestion and edema of the mucosa, and mucosal neutrophil infiltration. For each condition, 6-10 loops were tested. Data is presented as mean \pm SEM. ${ }^{A} P<0.05,{ }^{B} P<0.01$ vs. control. sample buffer. NT content was determined using a commercially available enzymatic immunoassay (EIA) kit (Peninsula Laboratories Inc., Belmont, California, USA). Protein concentrations were determined by the bicinchoninic acid protein ssay reagent (Pierce Chemical Co., Rockford, Illinois, USA). (traction of mucosal RNA and semiquantitative measurements of mucosal RNA was extracted from the colonic mucosa of toxin yanate/cesium chloride ultracentrifugation method (28). The integrity was determined by electrophoresis through a $1 \%$ of total mucosal RNA were reverse-transcribed. The cDNA $24)$. The temperature profile for the amplification reaction and the sequence for NT and NTR primers were as reported ase (GAPDH) (CLONTECH Laboratories Inc., Palo Alto, Calin, USA) primers were used as an internal standard as eported previously (24). Part of the amplification reactions $(10 \mu \mathrm{l})$ was analyzed directly on a $3.5 \%$ or $5 \%$ polyacrylamide Tris-EDTA buffer. The gels were then dried and exposed to Kodak X-OMAT AR film (Eastman Kodak Co.,

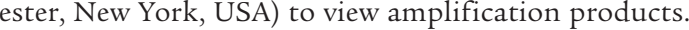
For semiquantitative analysis of NT and NTR mRNA expression, the films were replaced on the gel, and the areas correcontent was determined by Cerenkov counting, and results expressed as the ratio of NT or NTR to GAPDH-associatincluded omission of either RNA or RT during reverse tranconditions was discarded.

colitis. The nonpeptide NT receptor antagonist which inhibits binding and functional effects of NT $(9,19,31)$, was generously provided by Sanofi Recherche (Toulouse, France). The compound was dissolved in DMSO $(1 \mathrm{mg} / \mathrm{ml})$ ediately before use. Fasting, anesthetized rats were injected intraperitoneally with the indicated doses of SR-48,692 or ehicle $15 \mathrm{~min}$ before a colonic loop was injected with toxin A enal pedicles were tied to prevent renal excretion of $\left[{ }^{3} \mathrm{H}\right] \mathrm{man}$ a bolus of $\left[{ }^{3} \mathrm{H}\right]$ mannitol $(10 \mu \mathrm{Ci}$, mannitol, 30 EN Research Products, Boston, Massa(23). Four hours mined as loop weight-to-length ratio, and mucosal permeability was quantitated as blood-to-lumen clearance of $\left[{ }^{3} \mathrm{H}\right]$ mannitol. Myeloperoxidase (MPO) activity was assayed in aliquots of mucosal scrapings as a measure of PMN mucosal infiltration, using a modification of Bradley's method $(23,27)$. Histologic damage was determined on hematoxylin and eosin (H\&E)-stained, paraffin-embedded, and formalin-fixed full-thickness colonic samples as described previously by us (32).

Effect of NT antagonist on toxin $A$-induced rat mast cell protease (RMCPII) release. The colon was removed 15 min after SR-48,692 or vehicle administration to rats, opened flat, and washed in sterile HBSS. Colonic explants $(2 \times 2 \mathrm{~mm})$ were prepared and placed in $1 \mathrm{ml}$ modified Krebs buffer (32). After $30 \mathrm{~min}$, the 
buffer was changed and explants were incubated with $5 \mu \mathrm{g}$ toxin A or vehicle. After $2 \mathrm{~h}$, RMCPII content was determined in the explant supernatants by ELISA (Moredun Animal Health Ltd., Edinburgh, Scotland) (32).

Effect of the SP antagonist CP-96,345 on NT-mediated RMCPII release in vitro. The colon was removed from normal rats, and colonic explants $(2 \times 2 \mathrm{~mm})$ were placed in $1 \mathrm{ml}$ modified Krebs buffer (32). The buffer was changed after $30 \mathrm{~min}$, and explants were incubated in fresh buffer containing $0.01 \mathrm{mM}$ of either the NT receptor antagonist SR-48,692, the SP receptor antagonist CP-96,345 or its inactive enantiomer CP-96,344, or vehicle alone. After $1 \mathrm{~h}$, $\mathrm{NT}\left(10^{-8} \mathrm{M}\right), \mathrm{SP}\left(10^{-8} \mathrm{M}\right)$, or vehicle was added to the explants, and after an additional $2 \mathrm{~h}$, RMCPII content was determined in explant supernatants by ELISA as described above.

In situ bybridization for NTR1 $m R N A$ in rat colon. A riboprobe complimentary to the distal 3' untranslated portion of NTR1 gene (NTR2.3; gift from M.J. Alexander, Boston University School of Medicine) was labeled with digoxigenin (DIG) and quantified following the manufacturer's instructions (Boehringer Mannheim, Indianapolis, Indiana, USA). Rat colonic sections $(5 \mu \mathrm{m})$ were briefly fixed in $4 \%$ paraformaldehyde-PBS ( $\mathrm{pH} 8.5$ ) and acetylated for $15 \mathrm{~min}$ at room temperature in freshly prepared $0.25 \%$ acetic anhydrate in $0.1 \mathrm{M}$ triethanolamine HCl-PBS buffer ( $\mathrm{pH}$ 8.0). In situ hybridization was performed in a moisture chamber overnight at $53^{\circ} \mathrm{C}$ using a DIG-NTR1 cRNA probe at a concentration of $4 \mathrm{ng} / \mu \mathrm{l}$ in hybridization buffer ( $50 \%$ formamide, $10 \%$ dextran sulfate, $4 \times$ standard saline citrate [SSC], $1 \times$ Denhart's solution, $0.1 \mathrm{mg} / \mathrm{ml}$ herring sperm DNA, $0.125 \mathrm{mg} / \mathrm{ml}$ tRNA, $0.1 \mathrm{mg} / \mathrm{ml}$ dithiothreitol). After hybridization, slides were digested with RNase (20 $\mu \mathrm{g} / \mathrm{ml}$ ) for $1 \mathrm{~h}$ at $37^{\circ} \mathrm{C}$ and washed with $2 \times \mathrm{SSC}, 1 \times \mathrm{SSC}$, and $0.1 \times$ SSC for $1 \mathrm{~h}$ each at $50-58^{\circ} \mathrm{C}$. The localization of NTR1 mRNA was observed after incubation of the sections with a fluorescein-labeled sheep anti-digoxigenin conjugate (Boehringer Mannheim) at a dilution of 1:6 in blocking serum (1\% donkey serum, $2 \% \mathrm{BSA}, 0.05 \mathrm{M} \mathrm{NH}_{4} \mathrm{Cl}$, and $0.1 \%$ Tween-20.). After multiple washings in $1 \times$ TBS $(0.05 \mathrm{M}$ Tris base, $0.15 \mathrm{M} \mathrm{NaCl})$, sections were mounted in a drop of $1 \mathrm{mg} / \mathrm{ml}$ of $\mathrm{N}$-propylgallate (Sigma Chemical Co.) to reduce photobleaching in 90\% glycerolPBS ( $\mathrm{pH}$ 8.5). The images were viewed by a confocal microscope (model MRC1024; Bio-Rad Microsciences, Cambridge, Massachusetts, USA) using Plan-Neofluar objectives (20x) and were digitally stored in Bio-Rad COMOS software.

Immunohistochemical determination of NTR1 protein expression during toxin A-induced colitis. Rat colonic sections were first washed with $1 \times$ TBS buffer and then fixed in $4 \%$ paraformaldehyde in PBS ( $\mathrm{pH}$ 8.5). Sections were next incubated for $30 \mathrm{~min}$ in 1\% hydrogen peroxide and then for $30 \mathrm{~min}$ in blocking serum as described above. The slides were then incubated for $1 \mathrm{~h}$ at room temperature with a rabbit anti-rat NTR1 polyclonal antibody at a 1:200 dilution. This antibody has been raised toward amino acids $1-28$ and 50-69 of the rat NTR1 (13). This antisera immunoprecipitated ${ }^{125} \mathrm{I}-\mathrm{NT}$ azide cross-linked to NT receptors from human Pc3 cells and chicken liver (33). It also immunos-

\section{Figure 1}

Toxin A administration increases NT content in rat colonic mucosa. One closed loop was prepared in the proximal colon of anesthetized rats and injected with either $5 \mu \mathrm{g}$ of toxin A or buffer (Control). At the indicated time points, animals were sacrificed, colonic loops were excised, and the mucosa was removed and processed for measurements of NT content. Arrow shows limit of detection. Each bar represents the mean \pm SEM of 6-8 loops for each experimental condition. ${ }^{*} P<0.05,{ }^{*} P<0.01$ vs. control. NT, neurotensin. tained NT receptors from Pc3 cells, chicken liver, and rat brain subjected to Western blotting (33). After washing three times (10 min each) in $1 \times$ TBS, sections were incubated for $1 \mathrm{~h}$ at room temperature with FITC-labeled anti-rabbit IgG (Jackson ImmunoResearch Laboratories Inc., West Grove, Pennsylvania, USA). After washing in TBS, the slides were mounted, examined, and photographed using a confocal microscope as described above $(20 \times$ or $32 \times)$. In separate experiments, slides were exposed to the anti-NTR1 antibody, which was preincubated with an excess of the peptides used to immunize the rabbits.

Statistical analyses. Data was analyzed using the SIGMA-STAT program (Jandel Scientific Software, San Rafael, California, USA). ANOVA with protected $t$ test was used for intergroup comparisons.

\section{Results}

Time course of toxin A-induced colitis. We first measured the time course of appearance of the secretory and inflammatory responses following intracolonic administration of toxin A. Toxin A administration had no significant effect on colonic fluid secretion and mucosal permeability after one hour. However, both these parameters were significantly increased after two hours, and further increased after four hours (Table 1). Neutrophil infiltration, congestion and edema, and epithelial cell damage correlated temporally with changes in permeability and fluid secretion (Table 1).

$N T$ content and NT $m R N A$ levels are increased in rat colonic mucosa during C. difficile toxin A-induced colitis. Intracolonic administration of toxin A caused a time-dependent elevation in mucosal NT content, with NT levels increasing by 2.6 -fold at 30 minutes and by fourfold after one hour (Fig. 1). Two hours after toxin A injection, NT levels were lower than they were at one hour, but this decline was not statistically significant (Fig. 1). To semiquantitate changes in the levels of NT mRNA, we performed RTPCR on total mucosal RNA. Our results showed that toxin A increased the relative abundance of NT mRNA by 5.5 -fold as early as 30 minutes after toxin administration and by 12.6 -fold after two hours, compared with control levels $(P<0.05$ and $P<0.01$, respectively; $n=4-6$ per group). These data indicate that increases in the abundance of both NT mRNA and NT peptide in rat colon precede the secretory and inflammatory changes in response to toxin A (compare Fig. 1 and Table 1).

The NT antagonist SR-48,692 inhibits toxin A-induced colitis. Pretreatment of rats with the NT receptor antagonist SR48,692 reduced toxin $\mathrm{A}$-induced increases in colonic secretion, mannitol permeability, and MPO activity (Table 2). Histologic evaluation of colonic sections indicated that SR-48,692 at $1 \mathrm{mg} / \mathrm{kg}$ significantly reduced neutrophil infiltration, congestion and edema of the

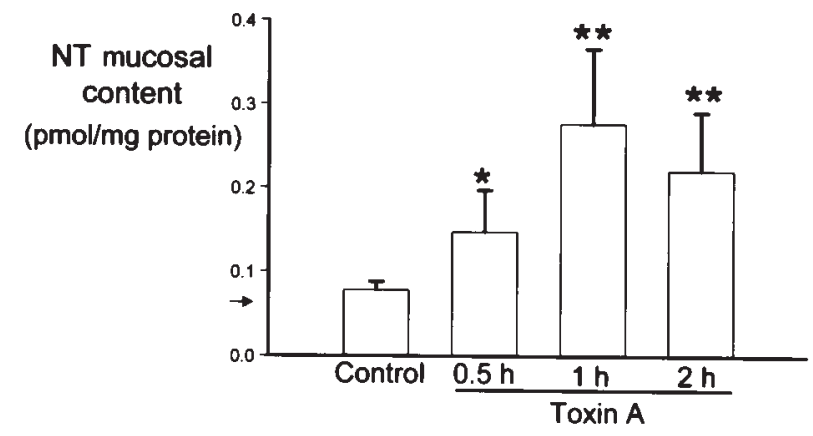


Table 2

Effects of pretreatment with SR-48,692 on toxin A-induced colitis

\begin{tabular}{|c|c|c|c|c|c|c|c|}
\hline & \multirow{2}{*}{$\begin{array}{l}\text { Intestinal } \\
\text { secretion } \\
(\mathrm{cm} / \mathrm{mg})\end{array}$} & \multirow{2}{*}{$\begin{array}{c}{\left[{ }^{3} \mathrm{H}\right] \text { mannitol }} \\
\text { permeability } \\
(\mathrm{dpm} / \mathrm{cm})\end{array}$} & \multirow{2}{*}{$\begin{array}{c}\text { MPO } \\
\text { activity } \\
(\mathrm{mU} / \mathrm{mg} \text { protein })\end{array}$} & \multirow{2}{*}{$\begin{array}{c}\text { RMCPII } \\
\text { release } \\
\text { (ng/mg tissue) }\end{array}$} & \multicolumn{3}{|c|}{ Histologic severity } \\
\hline & & & & & $\begin{array}{l}\text { Epithelial } \\
\text { damage }\end{array}$ & $\begin{array}{l}\text { Congestion and } \\
\text { edema }\end{array}$ & $\begin{array}{l}\text { Neutrophil } \\
\text { infiltration }\end{array}$ \\
\hline Control & $150 \pm 9$ & $1,220 \pm 410$ & $231 \pm 2$ & $0.96 \pm 0.28$ & $0.2 \pm 0.1$ & $0.3 \pm 0.2$ & $0.2 \pm 0.2$ \\
\hline Toxin A + & $\begin{array}{l}436 \pm 11^{\mathrm{A}} \\
189 \pm 10^{\mathrm{B}, \mathrm{C}}\end{array}$ & $\begin{array}{l}9,680 \pm 90^{\mathrm{B}} \\
6,400 \pm 1,670^{\mathrm{B}, \mathrm{C}}\end{array}$ & $\begin{array}{r}5,303 \pm \\
552 \pm 128^{\mathrm{B}, \mathrm{C}}\end{array}$ & $1.80 \pm 0.4^{B, C}$ & $\begin{array}{l}2.0 \pm 0.3^{B} \\
0.6 \pm 0.6^{B, C}\end{array}$ & $\begin{array}{l}2.2 \pm 0.3^{\mathrm{B}} \\
0.7 \pm 0.5^{\mathrm{B}, \mathrm{C}}\end{array}$ & $\begin{array}{l}2.4 \pm 0.2^{\mathrm{B}, \mathrm{C}} \\
1.0 \pm 0.3^{\mathrm{B}}\end{array}$ \\
\hline
\end{tabular}

Rats were treated (intraperitoneally) with $1 \mathrm{mg} / \mathrm{kg}$ of SR-48,692 or vehicle alone, and after 30 min, colonic loops were prepared and injected with $5 \mu \mathrm{g}$ of toxin $\mathrm{A}$ or buffer (control). After $4 \mathrm{~h}$, animals were sacrificed, colonic loops were removed, and fluid secretion, mucosal permeability to [ $\left.{ }^{3} \mathrm{H}\right]$ mannitol, mucosal MPO activity in colonic mucosal scrapings, and histologic severity of colitis were measured as in Table 1. In other experiments, colonic explants obtained from vehicle or SR48,642 -treated rats were exposed in vitro to toxin A $(5 \mu \mathrm{g} / \mathrm{ml})$ or buffer, and after $2 \mathrm{~h}$ incubation, mucosal mast cell degranulation was determined by RMCPII released into the culture media. Data are presented as mean \pm SEM of $6-12$ animals per group. ${ }^{A} P<0.01,{ }^{B} P<0.05$ vs. control; ${ }^{C} P<0.01$ vs. toxin $A$ alone. MPO, myeloperoxidase; RMCPII, rat mast cell protease.

mucosa, and the epithelial cell damage caused by toxin A (Table 2). SR-48,642 administration at doses of 100 and $10 \mu \mathrm{g} / \mathrm{kg}(n=6-12$ per group) significantly inhibited toxin A-mediated secretion (by $28 \%$ and $15 \%$ respectively; $P<0.05$ ), $\left[{ }^{3} \mathrm{H}\right]$ mannitol permeability (by $25 \%$ and $18 \%$, respectively; $P<0.05$ ), and MPO activity (by $76 \%, P<0.01$; and by $41 \%, P<0.05$, respectively). Administration of 1 $\mu \mathrm{g} / \mathrm{kg}$ of SR-48,642 did not significantly inhibit toxin A-mediated secretion, permeability, or MPO activity. These results strongly suggest that NT participates in the intestinal effects of $C$. difficile toxin A in rat colon in vivo.

The NT antagonist SR-48,692 inhibits toxin A-induced mast cell degranulation. Because toxin A is known to activate mucosal mast cells in vivo and in vitro $(23,26)$, and since NT-induced mast-cell degranulation in vitro is blocked by SR-48,692 (9), we examined the effect of SR-48,692 pretreatment on toxin A-induced mucosal mast cell degranulation in rat colonic explants. Exposure of colonic explants from vehicle-injected animals to toxin A for two hours increased release of the specific rat mast cell product RMCPII, while pretreatment of rats with SR48,692 inhibited this increase by $88 \%$ (Table 2 ).

NTR1 $m R N A$ and NTR1 protein are upregulated in the colonic mucosa during toxin A colitis. Hybridization of control sections with an antisense riboprobe for NTR1 mRNA showed the presence of modest signal in the colonic mucosa (Fig. 2a), consistent with previous findings (19). However, in tissues obtained from loops exposed to toxin A for one hour, a dramatic increase in the abundance of NTR1 mRNA was seen (Fig. 2b). The distribution of the signal in the mucosa appeared uneven: epithelial cells, mainly in colonic glands, and cells in the lamina propria, expressed NTR1 mRNA (Fig. 2b). In addition, detectable signal was also present in cells of the muscularis layer (Fig. $2 b$ ). Signal was nearly absent when toxin A-treated loops were hybridized with a sense riboprobe encoding the NTR1 mRNA (Fig. 2c). A semiquantitative analysis of NTR1 mRNA levels performed by RT-PCR showed that toxin A increased the relative abundance of NTR1 mRNA by 1.5 -fold 30 minutes after toxin administration and by 9.5-fold after 60 minutes, compared with control levels $(P$ $<0.05$ and $P<0.01$, respectively; $n=5$ per group). These data indicate that NTR1 mRNA levels are increased during the early stages of toxin A-induced colitis.

A similar pattern of immunohistochemical staining of colonic sections was obtained using antisera directed toward two peptides from the $\mathrm{NH}_{2}$-terminal region of NTR1. Staining of control loops revealed few NTR1positive mucosal cells (Fig. 3a). At two hours after injection of toxin $\mathrm{A}$, an increase in the immunostaining for NTR1 was evident mainly in the plasma membrane of colonic cells (Fig. 3b). Staining was most evident in the
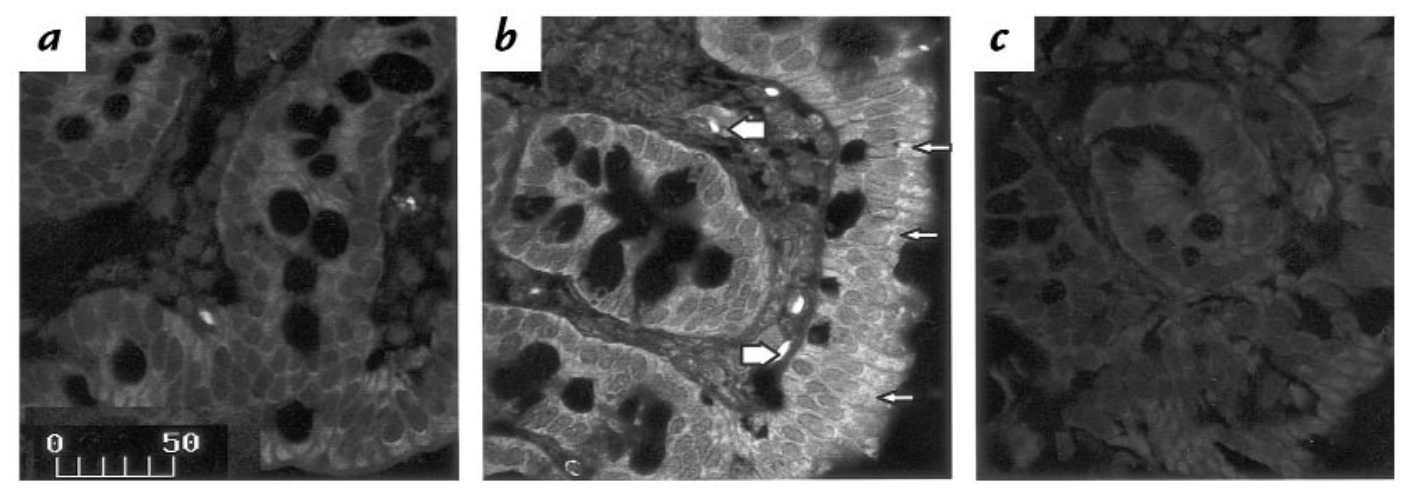

\section{Figure 2}

Increased NTR1 mRNA expression during toxin A-induced colitis in rats. Rat colonic loops were exposed to either toxin A or buffer. After $1 \mathrm{~h}$, animals were sacrificed, and colonic tissues were processed for in situ hybridization using 383-base-digoxigenin-labeled antisense riboprobe encoding for the NTR1 mRNA. Tissues were examined by confocal microscopy. (a) Section from a rat colon exposed only to buffer shows the presence of little hybridization signal in the epithelial layer and in cells of the lamina propria. (b) Colon exposed for $1 \mathrm{~h}$ to toxin A shows increased signal for the NTR1 mRNA primarily in intestinal epithelial cells (arrows), but also in cells of the lamina propria (arrowheads). (c) Colon from toxin A-exposed loop hybridized with a sense riboprobe encoding for the NTR1 mRNA shows absence of specific signal. Results are representative of three experiments for each experimental condition. Scale bar: $50 \mu \mathrm{m}$. NTR1, NT receptor-1. 


\section{Figure 3}

Increased NTR1 protein expression during toxin A colitis in rats. Rat colonic loops were injected with either toxin A ( $5 \mu \mathrm{g})$ or buffer (control). Animals were sacrificed after $2 \mathrm{~h}$, and colonic tissues were processed for immunohistochemical detection using a rabbit polyclonal antibody directed against the $\mathrm{NH}_{2}$-terminal amino acids 1-28 and 50-69 of the rat NTR1 receptor. Sections were examined by confocal microscopy. (a) Buffer-exposed colon ( $2 \mathrm{~h}$ ). (b) Toxin A-exposed colon (2 h). (c) Toxin A-exposed colon ( $2 \mathrm{~h}$ ) incubated with the NTR1 antiserum, which was preincubated with an excess of the two $\mathrm{NH}_{2}$-terminal peptides of the NTR1 described above. (d) Higher magnification of $b$. Note the presence of signal for NTR1 in the colonic mucosa, in particular the colonic epithelial cells (arrows in $b$ and $d$ ), and in cells in the lamina propria (arrowhead). Note also the increased immunoreactivity after $2 \mathrm{~h}$ exposure to toxin $\mathrm{A}(b)$ compared with control (a). Preabsorption of the NTR1 antiserum with an excess of the receptor peptides used to generate the antibody causes complete disappearance of positive staining in toxin A-exposed colon (c). Results are representative of three experiments for each experimental condition. Scale bar: $50 \mu \mathrm{m}$.
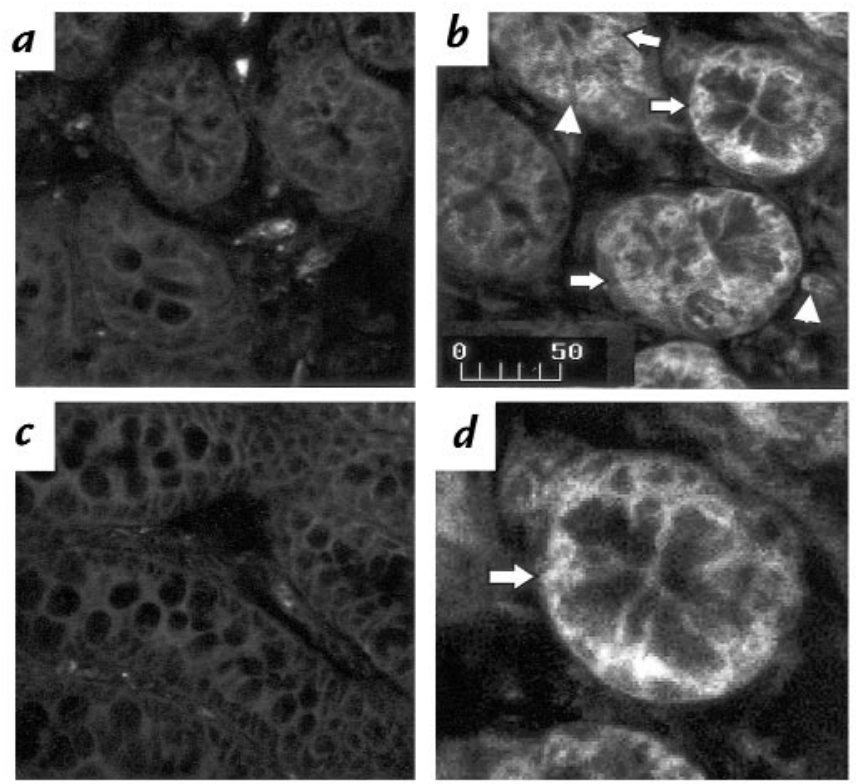

epithelium but was also present in the lamina propria (Fig. 3, $b$ and $d$ ). No staining was observed after adsorption of the antiserum with the peptide antigen (Fig. 3c).

The SP antagonist CP-96,345 inhibits NT-mediated mast cell degranulation. Because we previously reported that toxin A-mediated activation of mucosal mast cells is SP-dependent $(26,32)$, we investigated whether NT-induced mast cell degranulation in rat colon involves release of SP. As shown in Fig. 4, exposure of colonic explants to $10^{-8} \mathrm{M}$ of NT or SP caused a significant release of RMCPII compared with explants exposed to medium alone. Preincubation of the explants with SR-48,692 inhibited NT-mediated mast cell degranulation (Fig. 4). Pretreatment of explants with the SP receptor antagonist CP-96,345 completely inhibited both SP-mediated ( $n=4, P<0.01$; data not shown) and NTmediated mast cell degranulation in the rat colon (Fig. 4). CP-96,344, the inactive enantiomer of the SP receptor antagonist, did not have any effect on this response (Fig. 4). These results suggest that in the rat colon, NT induces mast cell degranulation through release of SP.

\section{Discussion}

To our knowledge the data presented here show for the first time the involvement of NT and the NTR1 receptor in the pathophysiology of acute colonic inflammation.
NT and NTR1 were elevated in rat colonic mucosa (Figs. 1-3) early during the course of C. difficile colitis and before significant increases in fluid secretion and mucosal permeability in response to toxin A were evident (Table 1). Furthermore, the NT receptor antagonist SR-48,692 inhibited colonic secretion, epithelial cell damage, neutrophil infiltration, and colonic mast cell degranulation in response to toxin A (Table 2). Our evidence also indicates that NT can degranulate colonic mast cells and that this effect is mediated via release of SP (Fig. 4).

In previous studies, we provided evidence that mucosal mast cells are critically involved in the pathophysiology of C. difficile toxin A-mediated enteritis $(23,26,32)$. We also demonstrated that NT can potently degranulate mast cells, releasing histamine and generating leukotrienes $(7,8)$. Furthermore the nonpeptide NT receptor antagonist SR-48,692 specifically blocked mast cell histamine release in vivo and in vitro in response to NT (9). Here we found that pretreatment of rats with SR48,692 at $1 \mathrm{mg} / \mathrm{kg}$ inhibited mucosal mast cell activation in response to toxin A (Table 2). These findings strongly suggest a critical involvement of NT or a related peptide in toxin A-induced mast cell activation. Inhibition of mast cell activation may also account for the reduced neutrophil infiltration observed in rats treated with the

\section{Figure 4}

The SP antagonist CP-96,345 inhibits NT-mediated mucosal mast cell degranulation in rat colon. Colonic explants $(2 \times 2 \mathrm{~mm})$ were cultured at $37^{\circ} \mathrm{C}$ in Krebs buffer alone or in buffer containing $0.1 \mathrm{mM}$ of either the SP receptor antagonist CP-96,345 or the NT receptor antagonist SR48,692. After $1 \mathrm{~h}$, either NT or SP $\left(10^{-8} \mathrm{M}\right)$ was added to the explants, and mucosal mast cell degranulation was determined after $2 \mathrm{~h}$ by measuring RMCPII released into the culture media. Both SP and NT caused a significant mast cell degranulation as measured by increased levels of RMCPII in the culture media. NT-induced mast cell degranulation was completely inhibited by the SP receptor antagonist CP-96,345, but not by its inactive enantiomer, CP-96,344. Data are presented as mean \pm SEM of four experiments, with triplicate determinations per group. ${ }^{*} P<0.01$ vs. control; ${ }^{++} P<0.01$ vs. NT alone. $S P$, substance $P$.

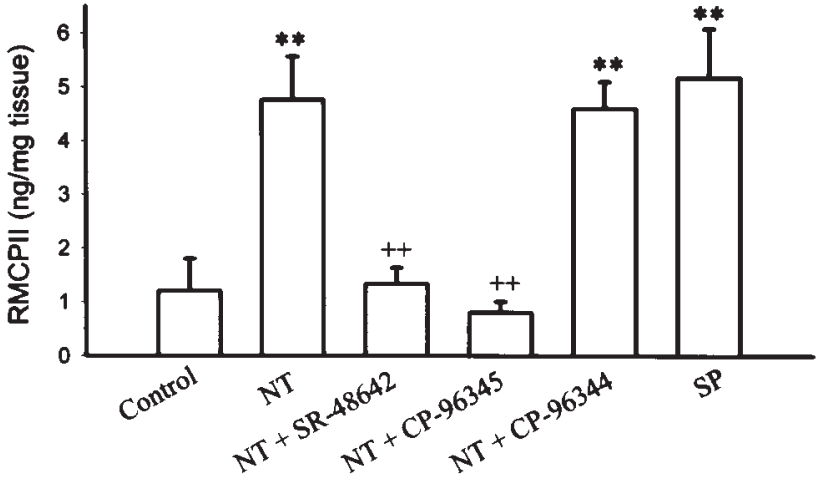


NT antagonist in our study (Table 2), because mast cell mediators are known to activate endothelial cells and initiate PMN chemotaxis in involved tissues (34).

Our results showed increased mucosal NT expression in the colonic mucosa in response to toxin A administration (Fig. 1). Consistent with earlier studies $(3,35)$, the levels of NT and its mRNA were very low but detectable in adult rat colon. It is well accepted that NT in the intestinal mucosa is primarily localized in endocrine $\mathrm{N}$ cells, which have their apices in direct contact with the intestinal lumen (3). Thus, $\mathrm{N}$ cells may sense the luminal content and release NT in response to specific stimuli (36). Furthermore, enteropathogenic viruses also increase NT blood levels (37), indicating a possible role for NT in the pathophysiology of diarrheal disorders. Thus, it is possible that toxin A stimulates NT release from mucosal N cells in the early phases of toxin A inflammation. NT might then stimulate neurons and immune cells of the lamina propria, including mast cells, to release proinflammatory mediators and other neuropeptides, thus initiating and/or amplifying the inflammatory response.

The involvement of primary sensory afferent neurons containing SP and calcitonin gene-related peptide (CGRP) in the intestinal effects of toxin A is well established $(23,24,32,38)$. The importance of SP and its neurokinin-1 (NK-1) receptor in toxin A-induced inflammation has been underscored by a recent study showing that mice deficient in NK-1 receptor have dramatically reduced intestinal responses to toxin A (39). In addition, the ability of NT to stimulate release of SP has been demonstrated in a number of experimental systems (40, 41). For example, NT causes release of SP from mesenteric ganglia by acting on primary afferent terminals (40), and NT-mediated contraction of guinea pig ileum involves activation of SP-releasing nerves (41). Furthermore, NT-induced increase in short-circuit current in guinea pig ileal mucosa in vitro is inhibited by prior desensitization of SP receptors (42). Here we demonstrate that, in rat colonic explants, NT-mediated mucosal mast cell degranulation is blocked by a specific antagonist to NK-1 receptor (Fig. 4). Thus, NT released from $\mathrm{N}$ cells or enteric neurons in response to toxin A (Fig. 1) may stimulate the release of substance $\mathrm{P}$, and possibly other peptides, initiating a cascade of neuro-immuno interactions leading to an acute inflammatory response within the colon $(24,32,39)$.

Here we provide evidence that NTR1 protein and mRNA are present in colonic epithelial cells and cells of the colonic lamina propria (Figs. 2 and 3), in keeping with results from our laboratory (19) and others' (16). Indirect evidence indicates the presence of functional NT receptors in enteric neurons (43) and immune and inflammatory cells, including peritoneal mast cells (7) and endothelial cells (18). However, so far there is limited direct evidence for presence of NTR1 mRNA or protein in any of these cells, including mucosal mast cells. Here we show increased expression of NTR1 mRNA (Fig. 2) and protein (Fig. 3) upon exposure of rat colon to toxin A. We did not directly investigate the nature of the cells in the lamina propria expressing NTR1 (Figs. 2 and 3). However, recent results indicate that rat intestinal macrophages express NTR1 mRNA upon stimulation with IL-1 $\beta$ (44). In addi- tion, we recently observed that human intestinal microvascular endothelial cells also express NTR1 and respond to neurotensin by releasing IL-8 (Castagliuolo, I., and Fiocchi, C., unpublished observations).

The finding that NT receptor upregulation occurs in the presence of increased levels of NT in the colonic mucosa is somewhat unexpected, because in vitro evidence indicates that agonist exposure induces loss of cell-surface receptors for NT (45). However, this finding is not without precedent. For example, increased mucosal SP content during the early stages of C. difficile toxin A-induced enteritis (24) is associated with upregulation of SP receptors (46). Similarly, SP binding sites are elevated in lymphoid aggregates and small blood vessels in colons of patients with inflammatory bowel disease (47), and SP content was found increased in the colonic mucosa of these patients (48). In a preliminary report we also showed that exposure of human colonic epithelial cells (HT-29) or umbilical vein endothelial cells to IL-1 $\beta$ resulted in increased NTR1 mRNA expression $(49,50)$. Based on these findings, we postulate that inflammatory mediators released during colonic inflammation can stimulate increased expression of NT receptors and overcome NT-mediated downregulation of its receptor.

In summary, our findings suggest a major proinflammatory role for NT and its receptor in acute, C. difficile toxin A-induced secretion and inflammation in rat colon. Our evidence indicates that the mechanism by which NT participates in colonic inflammation may involve release of SP from enteric and/or primary sensory nerves, which, in turn, can stimulate mast cell degranulation and colonic inflammation. Finally, the fact that NT and its receptor participate in both stress-induced colonic responses (19) and, as shown here, in enterotoxin-induced colonic inflammation, may indicate an important role for this peptide in the pathway(s) by which brain-gut interactions modulate inflammatory responses.

\section{Acknowledgments}

This study was supported by National Institutes of Health grants DK-47343 (to C. Pothoulakis) and DK-28565 (to R.E. Carraway), and by a Career Development Award (to I. Castagliuolo) from the Crohn's and Colitis Foundation of America Inc.

1. Cooke, H.J. 1994. Neuroimmune signaling in regulation of intestinal ion transport. Am. J. Physiol. 266:G167-G178.

2. Carraway, R.E., and Leeman, S.E. 1973. The isolation of a new hypotensive peptide, neurotensin, from bovine hypothalamus. J. Biol. Chem. 248: 6854-6861.

3. Walsh, J.H. 1987. Gastrointestinal hormones. In Physiology of the gastrointestinal tract. L.R. Johnson, editor. Raven Press. New York, NY. 324-340.

4. Kachur, J.F., Miller, R.J., Field, M., and Rivier, J. 1982. Neurohumoral control of ileal electrolyte transport II. Neurotensin and substance P. J. Pharmacol. Exp. Ther. 220:456-483.

5. Eklund, S., et al. 1987. Mechanisms of neurotensin-induced fluid secretion in the cat ileum in vivo. Acta Physiol. Scand. 129:203-210.

6. Riegler, M., et al. 1998. Neurotensin induces chloride secretion in human colonic mucosa through an adenosine-dependent pathway. Gastroenterology. 114:G4804. (Abstr.)

7. Carraway, R.E., et al. 1982. Neurotensin stimulates exocytotic histamine secretion from rat mast cells and elevates plasma histamine levels. J. Physiol. 323:403-414.

8. Carraway, R.E., et al. 1991. Neurotensin elevates hematocrit and plasma levels of the leukotriene LTB4, LTC4, LTD4 and LTE4 in anesthetized rats. Peptides. 12:1105-1111.

9. Miller, L.A., Cochrane, D.E., Carraway, R.E., and Feldberg, G. 1995. Blockade of mast cell histamine secretion in response to neurotensin by SR48692, a nonpeptide antagonist of the neurotensin brain receptor. $B r$. J. Pharmacol. 114:1466-1470. 
10. Goldman, R., Bar-Shavit, Z., and Romeo, D. 1983. Neurotensin modulates human neutrophil locomotion and phagocytic capability. FEBS Lett. 159:63-67.

11. Bar-Shavit, Z., Terry, S., Blumberg, S., and Goldman, R. 1982. Neurotensin-macrophage interaction: binding and augmentation of phagocytosis. Neuropeptides. 2:325-335.

12. Lemaire, I. 1988. Neurotensin enhances IL-1 production by activated alveolar macrophages. J. Immunol. 140:2983-2988.

13. Tanaka, K., Masu, M., and Nakanishi, S. 1990. Structure and functional expression of the cloned rat neurotensin receptor. Neuron. 4:847-854.

14. Mazella, J., et al. 1996. Structure, functional expression and cerebral localization of the levocabastine-sensitive neurotensin/neuromedin $\mathrm{N}$ receptor from mouse brain. J. Neurosci. 16:5613-5620.

15. Vita, N., et al. 1993. Cloning and expression of a complementary DNA encoding a high affinity human neurotensin receptor. FEBS Lett. 317:139-142.

16. Augeron, C., et al. 1992. Neurotensin and neuromedin $\mathrm{N}$ stimulate mucin output from human goblet cells(Cl.16E) via neurotensin receptors. Am. J. Physiol. 262:G470-G476.

17. Maoret, J.J, et al. 1994. Neurotensin receptors and its mRNA are expressed in many colon cancer cell lines but not normal colonic epithelium: binding studies and RT-PCR experiments. Biochem. Biophys. Res. Commun. 203:465-471.

18. Schaeffer, P., et al. 1995. Human umbilical vein endothelial cells express high affinity neurotensin receptors coupled to intracellular calcium release. J. Biol. Chem. 1270:3409-3413.

19. Castagliuolo, I., et al. 1996. A neurotensin antagonist, SR-48,692, inhibits colonic responses to immobilization stress in rats. Proc. Natl. Acad. Sci. USA. 93:12611-12615.

20. Pothoulakis, C. 1996. Pathogenesis of Clostridium difficile-associated diarrhoea Eur. J. Gastroenterol. Hepatol. 8:1041-1047.

21. Just, I., et al. 1995. Glucosylation of Rho proteins by Clostridium difficile toxin B. Nature. 375:500-503.

22. Martin, R., et al. 1995. Clostridium difficile toxin B is more potent than toxin A in damaging human colonic epithelium in vitro. J. Clin. Invest. 95:2004-2011.

23. Castagliuolo, I., et al. 1994. Neuronal involvement in the intestinal effects of Clostridium difficile toxin A and Vibrio choleare enterotoxin. Gastroenterology. 107:657-665.

24. Castagliuolo, I., et al. 1997. Increased substance P responses in dorsal root ganglia and intestinal macrophages during Clostridium difficile toxin A enteritis in rats. Proc. Natl. Acad. Sci. USA. 94:4788-4793.

25. Mantyh, C.R., et al. 1996. Substance P activation of enteric neurons in response to intraluminal Clostridium difficile toxin A in rat ileum. Gastroenterology. 111:1272-1280.

26. Wershil, B.K., Castagliuolo, I., and Pothoulakis, C. 1998. Direct evidence for mast cell involvement in Clostridium difficile toxin A induced enteritis in mice. Gastroenterology. 114:956-964.

27. Kelly, C.P., et al. 1994. Neutrophil recruitment in Clostridium difficile toxin A enteritis in rabbit. J. Clin. Invest. 93:1257-1265.

28. MacDonald, R.J., Swift, G.H., Przybyla, A.E., and Chirgwin, J.M. 1987. Isolation of RNA using guanidinium salts. Methods Enzymol. 152:219-227.

29. Komminoth, P., Long, A.A., Ray, R., and Wolfe, H.J. 1992. In situ polymerase chain reaction detection of viral DNA, single-copy genes, and gene rearrangements in cells suspensions and cytospins. Diagn. Mol. Pathol. 1:85-97.

30. Sovare, F., Ntodou-Thome, A., Tran, C.Y., Rostene, W., and Forgez, P. 1996. Quantitative RT-PCR: limits and accuracy. Biotechniques 21:280-285.

31. Gully, D., Canton, M., Boigegrain, R., and Jeanjean, F. 1993. Biochemi- cal and pharmacological profile of a potent and selective nonpeptide antagonist of the neurotensin receptor. Proc. Natl. Acad. Sci. USA. 90:65-67.

32. Pothoulakis, C., et al. 1994. CP-96,345, a specific substance P receptor antagonist inhibits rat intestinal responses to toxin A, but not cholera toxin. Proc. Natl. Acad. Sci. USA. 91:947-951.

33. Feldberg, R.S., et al. 1998. Evidence for a neurotensin receptor in rat serosal mast cells. Inflamm. Res. 47:245-250.

34. Wershil, B.K., Furuta, G.T., Wang, Z.-S., and Galli, S.J. 1996. Mast celldependent neutrophil and mononuclear cell recruitment in immunoglobulin E-induced gastritis reactions in mice. Gastroenterology. 110:1482-1490.

35. Muraki, K., Mitra, S.P., Dobner, P.R., and Carraway, R.E. 1993. Enhanced expression of neurotensin/neuromedin N mRNA and products of NT/NMN precursor processing in neonatal rats. Peptides. 14:1095-1102.

36. Rosell, S., and Rokaeus, A. 1979. The effect of ingestion of amino acids, glucose and fat on circulating neurotensin-like immunoreactivity in man. Acta Physiol. Scand. 107:263-267.

37. Hall, G.A., Parsons, K.R., and Bridger, J.C. 1985. Plasma enteroglucagon and neurotensin levels in gnotobiotic calves infected with enteropathogenic and non-enteropathogenic viruses. Res. Vet. Sci. 38:99-103.

38. Keates, A., et al. 1998. CGRP upregulation in dorsal root ganglia and ileal mucosa during Clostridium difficile toxin A-induced enteritis. Am. J. Physiol. 274:G196-G202.

39. Castagliuolo, I., et al. 1998. Neurokinin-1 (NK-1) receptor is required in Clostridium difficile-induced enteritis. J. Clin. Invest. 101:1547-1550.

40. Stapelfeldt, W.H., and Szurszewski, J.H. 1989. Neurotensin facilitates release of substance $\mathrm{P}$ in the guinea pig inferior mesenteric ganglion. $J$. Physiol. 411:325-345.

41. Carraway, R.E., and Mitra, S.P. 1994. Binding and biologic activity of neurotensin in guinea pig ileum. Peptides. 15:1451-1459.

42. Kachur, J.F., Miller, R.J., Field, M., and Rivier, J. 1982. Neurohumoral control of ileal electrolyte transport. II. Neurotensin and substance P. J. Pharmacol. Exp. Ther. 220:456-463.

43. Kitabgi, P., Checler, F., Mazzella, J., and Vincent, J.P. 1985. Neurotensin: topographical distribution in the rat brain by immunohistochemistry. Rev. Clin. Basic Pharm. 5:397-486.

44. Castagliuolo, I., et al. 1998. IL-1 $\beta$ stimulates release of substance P and neurotensin and increases expression of their receptors on lamina propria macrophages. Gastroenterology. 114:G4638. (Abstr.)

45. Vanisberg, M.A., Maloteaux, J.M., Octave, J.N., and Laduron, P.M. 1991. Rapid agonist-induced decrease of neurotensin receptors from the cell surface in rat cultured neurons. Biochem. Pharmacol. 42: 2265-2274.

46. Pothoulakis, C., et al. 1995. Increased substance $P$ and substance P receptor expression (mRNA SPR) in Clostridium difficile toxin A-mediated enteritis in rats. Am. J. Physiol. 275:G68-G75.

47. Mantyh, C.R., et al. 1988. Receptor binding sites for substance P, but not substance $\mathrm{K}$ or neuromedin $\mathrm{K}$, are expressed in high concentrations by arterioles, venules, and lymph nodules in surgical specimens obtained from patients with ulcerative colitis and Crohn disease. Proc. Natl. Acad. Sci. USA. 85:3235-3239.

48. Sharkey, K.A. 1992. Substance P and calcitonin gene-related peptide (CGRP) in gastrointestinal inflammation. Ann. NY Acad. Sci. 664:425-442.

49. Pasha, A., et al. 1998. Increased neurotensin receptor mRNA in the colonic mucosa during Clostridium difficile pseudomembranous colitis in humans. Gastroenterology. 114:G4333. (Abstr.)

50. Pasha, A., Castagliuolo, I., Carraway, R., and Pothoulakis, C. 1997. Neurotensin receptor modulation in human umbilical vein endothelial cells in vitro. Gastroenterology. 112:A1179. (Abstr.) 